\title{
EVALUASI PERANCANGAN TRASE JALAN JALUR PUNCAK 2 ALTERNATIF I (DESA SUKANAGALIH PACET CIANJUR PERBATASAN KABUPATEN BOGOR)
}

\author{
${ }^{1}$ Zihan Fitriyani, ${ }^{2}$ Yudi Sekaryadi \\ Program Studi Teknik Sipil Fakultas Teknik Universitas Suryakancana \\ zihanf945@gmail.com 1; yudisekaryadi65@gmail.com²
}

\begin{abstract}
Abstrak
Perencanaan Trase Jalan Jalur Puncak 2 Alternatif 1 (Desa Sukanagalih Pacet Cianjur Perbatasan Kabupaten Bogor) merupakan salah satu jalan dengan type jalan 1 jalur, 2 arah yang berstatus jalan nasional. Pembangunan Jalur Puncak 2 berfungsi untuk mengurangi kemacetan di jalan jalur puncak 1. Jalur puncak 2 nantinya akan menjadi jalur utama. Tujuan penelitian adalah merencanakan bentuk geometrik jalan sesuai kelas dan fungsinya, yaitu jalan arteri kelas I, guna menghasilkan geometrik jalan yang memberikan kelancaran, keamanan, dan kenyamanan bagi pemakai jalan. Metode yang di gunakan adalah metode Bina Marga No. 038 T/BM/1997. Untuk menunjang studi ini diperlukan beberapa data seperti : data volume lalu lintas, data curah hujan, data CBR, dan juga data analisa harga satuan. Dari hasil data yang diperoleh kemudian diolah dan dianalisa pada perhitungan perkerasan lentur jalan baru dengan standar Bina Marga, analisa perkerasan jalan ini menggunakan Petunjuk Perencanaan Tebal Perkerasan Lentur Jalan Raya Dengan Metode Analisa Komponen (SKBI-2.3.26.1989). Dari hasil dari perencanaan geometrik jalan dengan panjang $8,06 \mathrm{~km}$, klasifikasi medan yang ada pada jalan rencana merupakan daerah bukit, kecepatan rencana $60 \mathrm{~km} / \mathrm{jam}$ dan lebar jalan yang direncanakan adalah 2x3,5 meter, direncanahan tikungan full circle dan tikungan Spiral-Circle-Spiral, sedangkan hasil perhitungan diperoleh tebal lapisan perkerasan lentur jalan baru dengan nilai lapisan permukaan LASTON (MS 744 $\mathrm{kg})=10 \mathrm{~cm}$, lapisan pondasi atas batu pecah kelas $B(C B R 80 \%)=20 \mathrm{~cm}$, lapisan pondasi bawah sirtu kelas $B(C B R 50 \%)=10 \mathrm{~cm}$, total biaya yang dibutuhkan adalah sebesar Rp. 138.982.761.000, diharapakn pada perencanaan ini bisa mendapatkan hasil analisa yang baik.
\end{abstract}

Kata Kunci : Geometrik Jalan, Perkerasan Lentur Jalan, Rencana Anggaran Biaya

\section{PENDAhUluan}

Perkembangan jalan raya merupakan salah satu hal yang selalu beriringan dengan kemajuan teknologi dan pemikiran manusia yang menggunakannya, jaringan jalan raya merupakan prasarana transportasi yang memiliki peranan penting terutama untuk memprasaranai kebutuhan akan transportasi untuk kelancaran mobilitas penduduk. Keberadaan jalan raya sangat diperlukan untuk menunjang laju pertumbuhan ekonomi masyarakat, seiring dengan meningkatnya pertumbuhan sarana transportasi. Keinginan pengguna jalan untuk sampai tujuan dengan selamat, serta kenyamanan pada saat perjalanan merupakan suatu standarisasi untuk penyediaan fasilitas prasarana transportasi yang baik.

Jadi jalan yang direncanakan harus mempunyai tingkat efisiensi, keamanan, kenyamanan yang cukup memadai sesuai dengan kondisi setempat baik secara teknis, ekonomi, maupun sosial.
Jalan jalur puncak 2 adalah jalan alternatif yang menghubungkan antara Kabupaten Cianjur dan Kabupaten Bogor yang merupakan jalan dengan type jalan 1 jalur, 2 arah. Berdasarkan statusnya jalan Jalur Puncak 2 ini adalah jalan nasional yang memegang peranan penting sebagai prasarana transportasi dalam pertumbuhan ekonomi masyarakat. Pembangunan Jalur Puncak 2 berfungsi untuk mengurangi kemacetan di jalan jalur puncak 1. Jalur puncak 2 nantinya akan menjadi jalur utama.

\section{METODOLOGI PENELITIAN}

\section{Data Umum}

Berikut adalah data umum trase jalan jalur puncak 2 alternatif 1 dari Bina Marga:

a. Perkiraan panjang penanganan $8.06 \mathrm{~km}$

b. Lebar perkerasan jalan dan bahu $10,00 \mathrm{~m}$

c. Lebar lahan yang dibutuhkan $30,00 \mathrm{~m}$

d. Perkiraan pekerjaan konstruksi Rp. 122,30 miliar 
e. Perhitungan volume masih berupa perkiraan kasar karena masih didasarkan pada photo Citra Satelit (31 Juli 2019), belum didasarkan hasil pengukuran di lapangan.

f. Type jalan 1 jalur, 2 lajur, dua arah dengan status jalan Arteri (kelas 1).

\section{Jenis dan Sumber Data}

a. Data Premier

Data primer yang diperoleh penulis yaitu dengan cara melakukan survey langsung kelapangan, selain untuk meninjau langsung kondisi perencanaan pekerjaan penyusun juga melakukan survey volume kendaraan guna untuk memperoleh data lalu lintas harian rata-rata (LHR). Data lalu lintas harian rata-rata (LHR) digunakan untuk merencanakan tebal perkerasan jalan dengan adanya tingkat pertumbuhan kendaraan rata-rata pertahun.

b. Data Sekunder

Data sekunder merupakan sumber data yang diperoleh dari pihak lain, baik secara langsung maupun tidak langsung. Data yang diperoleh penulis adalah sebagai berikut: (1). Data topografi didapat dari dinas PUPR kabupaten Cianjur yang menggunakan citra satelit. Peta topografi yaitu menggambarkan relief permukaan bumi beserta bangunan alami maupun buatan manusia yang ada diatasnya atau peta yang menggambarkan relief/sifat permukaan bumi yang digambarkan dengan garis kontur.

(2). Data curah hujan tahunan maksimum, sangat diperlukan guna untuk menghitung tinggi hujan rencana dan periode ulang. Data curah hujan yang dimasksud adalah data curah hujan pada stasiun pengamatan wilayah Cipanas yaitu pada tahun 2011 sampai dengan 2019 yaitu rata-rata $1438 \mathrm{~mm} /$ tahun.

(3). Uji CBR merupakan standar tes untuk mengetahui kekuatan tanah. Kekuatan tanah dasar seperti yang ada di lapangan seperti nilai CBR tergantung pada kondisi pada saat pelaksanaan dan selama pelayanan operasi berlangsung.

\section{PEMBAHASAN}

Peta topografi skala $1: 50.000$ dilakukan perbesaran pada daerah yang akan dibuat trase jalan menjadil : 10.000, dan di perbesar lagi menjadi 1 : 5000, trase digambar dengan memperhatikan kontur tanah yang ada.

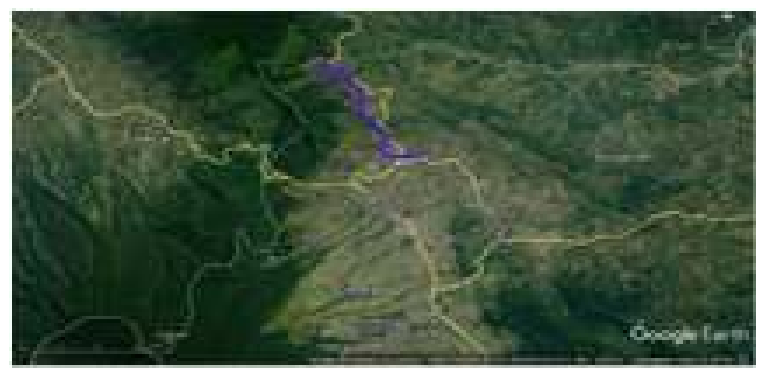

Gambar 4.1. Peta Topografi Jalur Puncak 2

\section{Perhitungan Geometrik Jalan}

Berikut adalah perhitungan geometric jalan jalur puncak 2 alternatif 1 :

a. Kelandaian Melintang

Data kelandaian melintang diketahui

kelandaian rata-rata adalah

$12.98 \%$ dengan medan perbukitan, untuk klasifikasi jalan arteri didapat kecepatan 60-80 $\mathrm{km} / \mathrm{jam}$. Maka diambil kecepatan $60 \mathrm{~km} / \mathrm{jam}$.

b. Perhitungan Alinyemen Horizontal

Dengan data: Peta yang dipakai menggunakan peta satelit, Kelas jalan Kelas 1 (Arteri), Klasifikasi medan: Bukit,

$$
\mathrm{Vr}=60 \mathrm{~km} / \text { jam }, e_{\max }=10 \%, e_{n}=
$$

$2 \%$, Lebar perkerasan $=2 \times 3.5 \mathrm{~m}, \mathbf{f} \mathbf{m a x}=$ 0.153 maka direncanakan tikungan PI 1 menggunakan tipr tikungan spiral-circlaspiral dengan hasil perhitungan:

$$
\begin{array}{ll}
\beta_{1}{ }^{\circ} & =68^{\circ} \\
\mathrm{Rc} & =143 \mathrm{~m} \\
e_{d} & =8.8^{\circ} \\
\mathrm{Ls} & =60 \mathrm{~m} \\
\theta \mathrm{\theta} & =12.03^{\circ} \\
\theta \mathrm{c} & =43.98^{\circ} \\
\mathrm{Lc} & =109.59 \mathrm{~m} \\
\mathrm{~L} & =229.59 \mathrm{~m} \\
\mathrm{P} & =1.005 \mathrm{~m} \\
\mathrm{~K} & =29.95 \\
\mathrm{Es} & =30.76 \mathrm{~m} \\
\mathrm{Ts} & =127.09
\end{array}
$$



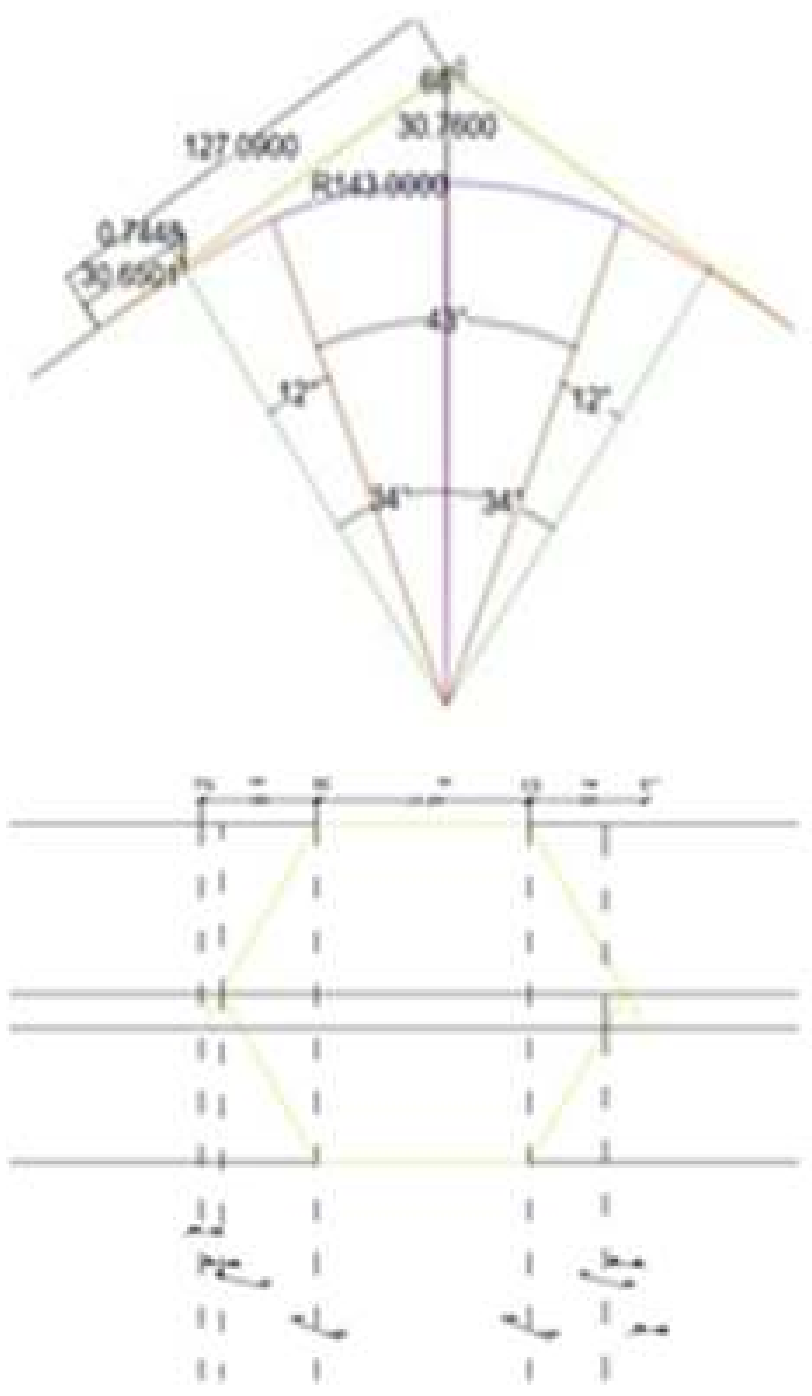

Gambar 4.2. Desain Alinyemen Horizontal tikungan PI 1

\section{Perkerasan Lentur}

Berikut data untuk perhitungan perkerasan lentur:

a. Klasifikasi jalan arteri.

b. Umur rencana jalan 10 tahun.

c. CBR tanah dasar $4 \%$.

d. Kelandaian jalan rata-rata $12.98 \%$.

e. Curah hujan rata-rata 1438 $\mathrm{mm} /$ tahun.

f. Data-data lalu lintas hasil survey lapangan pada tahun 2020 terdiri dari:

1. Kendaraan ringan 2 ton $(1+1)$ $=4051 /$ hari

2. Bus kecil 4 ton $(2+2)=34$ /hari

3. Bus besar 8 ton $(3+5)=76$ /hari

4. Truk 2 AS 8 ton $(3+5)=57 /$ hari

5. Truk 2 AS 13 ton $(5+8)=16 /$ hari

$$
\Sigma \text { LHR }=4234
$$

g. Tingkat pertumbuhan lalu lintas selama umur rencana jalan 5\%/tahun

h. Konstruksi jalan yang akan dibuat terdiri dari:

- Lapisan permukaan LASTON (MS 744 $\mathrm{kg})$

- o Lapisan pondasi atas batu pecah kelas B (CBR 80\%)

- Lapisan pondasi bawah sirtu kelas B (CBR 50\%)

Hasil perhitungan menggunakan data diatas didapat tebal perkerasan Lapisan permukaan menggunaka Laston MS 744 dengan tebal $10 \mathrm{~cm}(\mathrm{AC}-\mathrm{WC} 4 \mathrm{~cm}$ dan AC-BC $6 \mathrm{~cm}$ ), lapisan pondasi atas menggunakan Batu pecah kelas B (CBR 80\%) dengan tebal $20 \mathrm{~cm}$, sedangkan lapisan pondasi bawah menggunakan Sirtu/Pitrun kelas B (CBR $50 \%$ ) dengan tebal $10 \mathrm{~cm}$.

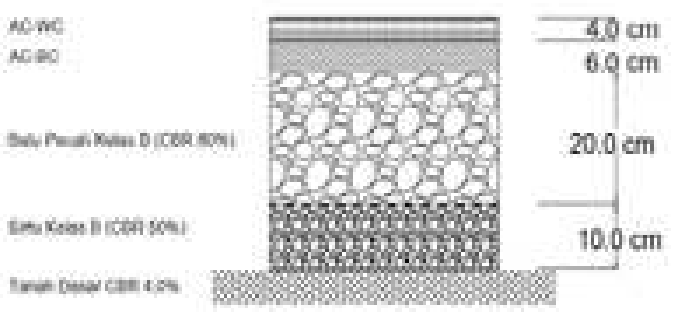

Gambar 4.3. Tebal Lapisan Perkerasan Jalan

\section{Rencana Anggaran Biaya}

Untuk pembangunan jalan ini diperlukan dana sebesar Rp. 138.982.761.000 (seratus tiga puluh delapan milyar sembilan ratus delapan puluh dua juta tujuh ratus enam puluh satu ribu rupiah).

\section{KESIMPULAN}

1. Trase jalan jalur puncak 2 alternatif 1 ini merupakan jalan arteri dengan spesifikasi jalan kelas 1 dimana panjang jalan $8060 \mathrm{~m}$, lebar perkerasan $2 \times 3.5 \mathrm{~m}$ dan lebar bahu jalan 2 x $1.5 \mathrm{~m}$.

2. Jalan ini dapat dilalui oleh kendaraan dengan kecepatan rencana jalan yaitu 60 $\mathrm{km} / \mathrm{jam}$.

3. Pada jalan ini terdapat tikungan jenis spiral-circle-spiral dan full circle.

4. Besar volume pekerjaan galian yaitu $1365000 \mathrm{~m} 3$ sedangkan pekerjaan timbunan sebesar $337500 \mathrm{~m} 3$.

5. Lapisan permukaan menggunaka Laston MS 744 dengan tebal $10 \mathrm{~cm}$ (AC-WC $4 \mathrm{~cm}$ dan AC-BC $6 \mathrm{~cm}$ ), lapisan pondasi atas menggunakan Batu pecah kelas B (CBR 
$80 \%$ ) dengan tebal $20 \mathrm{~cm}$, sedangkan lapisan pondasi bawah menggunakan Sirtu/Pitrun kelas B (CBR 50\%) dengan tebal $10 \mathrm{~cm}$.

6. Untuk pembangunan jalan ini diperlukan dana sebesar Rp. 138.982.761.000 (seratus tiga puluh delapan milyar sembilan ratus delapan puluh dua juta tujuh ratus enam puluh satu ribu rupiah).

\section{DAFTAR PUSTAKA}

Departemen Pekerjaan Umum Direktorat Jendral Bina Marga. Spesipikasi Umum 2018 Untuk Pekerjaan Kontruksi Jalan dan Jembatan. Badan Penerbit Pekerjaan Umum. Jakarta: 2018.

Departemen Pekerjaan Umum Direktorat Jendral Bina Marga Jalan No.038/T/BM/1997.Tatacara Perenca naan Geometrik Jalan Antar Kota. Badan Penerbit Pekerjaan Umum. Jakarta: 1997.

Departemen Pekerjaan Umum Direktorat Jendral Bina Marga. Petunjuk Perencanaan Tebal Perkerasan Lentur Jalan Raya Dengan Analisa Komponen. Badan Penerbit Pekerjaan Umum. Jakarta: 1989.

Silvia Sukirman. Dasar-dasar Perencanaan Geometrik Jalan, Nova. Bandung: 1995.

Silvia Sukirman. Dasar-dasar Perencanaan Geometrik Jalan, Nova. Bandung:1995. 